\title{
Cell proliferation patterns in the equine endometrium throughout the non-pregnant reproductive cycle
}

\author{
C. Gerstenberg ${ }^{1}$, W. R. Allen ${ }^{1}$ and F. Stewart ${ }^{1,2 *}$ \\ 'University of Cambridge Department of Clinical Veterinary Medicine, Equine Fertility Unit, Mertoun Paddocks, Newmarket, \\ Suffolk CB8 9BH, UK; and ' ${ }^{2}$ The Babraham Institute, Babraham, Cambridge CB2 4AT, UK
}

\begin{abstract}
Immunohistochemical detection of the proliferation marker Ki-67 antigen was used to monitor mitotic activity in the endometrium of mares. The monoclonal antibody MIB1 was validated for use on equine tissues by demonstrating its reaction with activated peripheral blood lymphocytes, and endometrial biopsies were recovered from 26 nonpregnant mares at selected stages during the reproductive cycle. The proportion of positively stained nuclei was counted in five random areas on each histological section to determine the percentage and type of proliferating cells. Multiplication rates in the types of cell found in the superficial strata, comprising the luminal epithelium, the epithelium of the gland necks and the stromal cells of the stratum compactum, were greatest during oestrus, presumably under the influence of oestrogens secreted by the growing ovarian follicles. In contrast, the mitotic activity in the cells of the deeper secretory portions of the endometrial glands was restricted to a brief phase between day 3 and day 7 of dioestrus, most likely as a delayed response to the decreasing oestrogen concentrations after ovulation. Some of the degenerate glands in subfertile mares did not follow this pattern of increased epithelial proliferation at that stage. After day 7 of dioestrus, the proliferation rates of cells in the endometrium decreased to basal values and remained low for as long as progesterone concentrations remained evaluated, even during prolonged dioestrus. The technique enabled characterization of normal cell proliferation patterns in the endometrium of mares and it will be a useful tool in the future for monitoring the endometrial responses of reproductively healthy and subfertile mares.
\end{abstract}

\section{Introduction}

As in all mucosal tissues, the endometrium, and especially its luminal and glandular epithelia, consist of populations of cells that are renewed constantly (Leblond, 1981). This process of cell proliferation, as well as the morphological and physiological changes that occur in the cells during the oestrous cycle, are thought to be controlled by the relative concentrations of the ovarian steroid hormones oestradiol and progesterone, and by the local actions of various growth factors (Pollard, 1990; Weitlauf, 1994). The inability of the endometrium to respond adequately to these hormonal stimuli may represent one of the causes of subfertility in mares. For example, the fertility of mares is reduced in early Spring if the reactivation of their endometrium from seasonal atrophy lags behind the recommencement of ovarian cyclicity (Kenney, 1978). Conception rates are reduced in this period of so-called 'residual endometrial atrophy' during the transitional phase when the tubular genitalia appear unable

${ }^{*}$ Correspondence address: The Babraham Institute, Babraham, Cambridge CB2 4AT, UK.

Received 14 September 1998. to react normally to the trophic stimuli of the steroid hormones (Kenney and Doig, 1986). Day 14 pregnancy rates are also low in subfertile mares that suffer chronic inflammatory and degenerative changes in the endometrium, although fertilization rates are normal (Ball et al., 1986). It has been suggested that a defective or asynchronous response of the endometrial glands to cyclic hormonal stimuli in these mares may contribute to their decreased fertility (Schoon $c t$ al., 1997).

Immunohistochemical localization of specific biochemical changes that occur during various stages of the cell cycle can be used to provide information on cell kinetics (Hall and Levison, 1990). For example, the monoclonal antibody Ki-67 reacts with a cell cycle-associated nuclear antigen (Gerdes $e t$ al., 1983) that is expressed in the nucleus at all stages of the mitotic cell cycle except in the resting phase (G0) (Gerdes et al., 1984). Detection of the Ki-67 antigen has been used to estimate successfully the growth rates of a variety of neoplastic and non-neoplastic tissues (Hall and Levison, 1990). In addition, it has been used to describe the proliferation of cells in the endometrium of women (Dowsett et al., 1995) and non-human primates (Slayden et al., 1993). The fact that the Ki-67 antigen appears to have been well 
conserved during evolution (Falini et al., 1989) means that antibodies that recognize it are potentially useful for other non-primate species.

The lamina propria of the equine endometrium is subdivided into the more superficial stratum compactum, which has a relatively high density of stromal fibroblasts, and the deeper stratum spongiosum, in which the connective tissue is arranged more loosely. The branched tubular glands are connected to the luminal epithelium by short straightneck regions, while their deeper coiled secretory portions are located in the stratum spongiosum (Kenney, 1978). The histological changes in the equine endometrium throughout the oestrous cycle have been described in detail by Hammond and Wodzicki (1941), Ricketts (1975), Kenney (1978) and others, but there is no comprehensive account of the pattern of proliferation of the various types of cell within the endometrium. On the contrary, there has been extensive work in this regard in women (Ferenczy et al., 1979; Johannisson et al., 1982; Dowsett et al., 1995), rhesus monkeys (Bartelmez, 1957; Padykula, 1989; Slayden et al., 1993), mice, rats, rabbits and guinea pigs (reviewed in Weitlauf, 1994), both to establish the normal proliferation patterns of the different types of cell and to investigate the effects of various exogenous steroid hormone treatments. There are crucial differences in structure and function between the endometria of these species, in which the uterus has to be able to support invasive types of placentation, and the endometrium of mares. The endometrium of women and rhesus monkeys is further specialized so that it can be shed and regenerate every month. Thus, it is not realistic to extrapolate data from other species to mares. The aim of this study was to use immunohistochemical detection of the Ki-67 antigen to establish proliferation patterns for the different types of cell in the endometrium of mares during the various stages of the oestrous cycle. The mouse monoclonal antibody MIB1, which recognizes $\mathrm{Ki}-67$ antigen in human tissues (Key et al., 1993), was first validated for use in horse tissues by assessing its reaction with activated equine peripheral blood lymphocytes.

\section{Materials and Methods}

\section{Preparation and stimulation of lymphocytes}

Whole blood was collected from the jugular vein of a mare into $15 \mathrm{ml}$ evacuated glass tubes, each containing $300 \mathrm{iu}$ heparin diluted in $0.5 \mathrm{ml}$ PBS. After centrifugation at $475 \mathrm{~g}$ for $15 \mathrm{~min}$, most of the plasma was discarded and the buffy coat was layered over a cushion of Histopaque (SigmaAldrich Co., Poole) for the removal of erythrocytes and phagocytic cells by gradient centrifugation. The peripheral blood lymphocytes isolated in this manner were washed several times in PBS before they were activated by adding $3 \times 10^{7}$ cells per $10 \mathrm{ml}$ to RPMI-1640 culture medium containing $2 \mathrm{mmol}$ L-glutamine $\mathrm{l}^{-1}, 50 \mathrm{iu}$ penicillin $\mathrm{ml}^{-1}$, $50 \mathrm{mg}$ streptomycin $\mathrm{ml}^{-1}, 0.01 \mathrm{mmol}$ 2-mercaptoethanol $\mathbf{l}^{-1}$, $10 \%(\mathrm{v} / \mathrm{v})$ heat inactivated fetal calf serum (FCS) and $1.25 \mathrm{mg}$ pokeweed mitogen $\mathrm{ml}^{-1}$ (all from Sigma-Aldrich; Allen GP et al., 1995). The cells were incubated in this mixture at $37^{\circ} \mathrm{C}$ for
$48 \mathrm{~h}$, after which dead cells were removed by gradient centrifugation using Histopaque. Small aliquots of the purified lymphoctes, both before and after mitogenic stimulation, were diluted in PBS and prepared for staining by cytospinning the cells onto glass slides coated with 3-aminopropyl-triethoxysilane (APTES; Sigma-Aldrich). The slides were then air dried, fixed in $4 \%(\mathrm{w} / \mathrm{v})$ paraformaldehyde, dehydrated and stored in $95 \%$ ethanol until processed for immunocytochemistry.

\section{Animals}

Endometrial biopsies were obtained from 26 barren or maiden mares aged 3-12 years. The animals were examined routinely by transrectal palpation and real-time ultrasound scanning of the reproductive tract to determine and monitor the stage of the oestrous cycle. Blood samples were taken regularly from the jugular vein to assay serum progesterone concentrations to confirm the occurrence and time of ovulation and to monitor luteal development (Allen and Sanderson, 1987). Day 1 of dioestrus was determined as the first day on which the serum progesterone concentrations exceeded $1 \mathrm{ng} \mathrm{ml}^{-1}$. An endometrial biopsy was obtained from each of three to five mares, respectively, during oestrus, early dioestrus (days 1-5), mid-dioestrus (days 7-10) and late dioestrus (day 14). During the month of January, biopsies were taken from five mares that were determined to be in seasonal anoestrus on the basis of low serum progesterone concentrations during five consecutive weeks, combined with an absence of follicles $>10 \mathrm{~mm}$ in diameter in their ovaries. In addition, endometrial biopsies were obtained from three mares that were judged to be in spontaneous prolonged dioestrus on the basis of serum progesterone concentrations of $>5 \mathrm{ng} \mathrm{ml}^{-1}$ in samples collected three times a week for $>30$ days (31-40 days).

\section{Endometrial biopsies}

The endometrial biopsies were obtained using Yeomantype biopsy forceps, either blindly by transrectal palpation of the uterus (Ricketts, 1975) or under visual control during videoendoscopic examination (Bracher and Allen, 1992). The samples were snap-frozen immediately in isopentane over liquid nitrogen and stored at $-70^{\circ} \mathrm{C}$ until sectioned. Cryosections of $6 \mu \mathrm{m}$ thickness were thaw-mounted onto slides coated with APTES, air-dried briefly, fixed in a $4 \%$ $(\mathrm{w} / \mathrm{v})$ paraformaldehyde solution, rinsed in PBS, dehydrated through an ethanol series, and stored in $95 \%$ ethanol at $4^{\circ} \mathrm{C}$ until processed.

\section{Immunohistochemistry}

Detection of the proliferation marker Ki-67 antigen with a monoclonal antibody (MIB1; Dianova, Hamburg) was used to determine nuclei that were in the process of dividing. The cytospins or endometrial sections were rehydrated through an ethanol series and then placed in Tris-buffered saline 
(TBS). The decision was taken not to quench endogenous peroxidase activity using a hydrogen peroxide incubation step because the treatment damaged the tissue architecture. After blocking for $20 \mathrm{~min}$ in 3\% TBS-BSA, the slides were incubated for $1 \mathrm{~h}$ at room temperature in a 1:200 dilution of the primary antibody (MIB1) in 3\% TBS-BSA. Negative control slides were incubated with $3 \%$ TBS-BSA alone. The avidin biotinylated horseradish peroxidase macromolecular complex $(\mathrm{ABC})$ detection system (mouse IgG, Vectastain $A B C$ kit) and the 3,3'-diaminobenzidine (DAB) peroxidase substrate kit (both from Vector Laboratories, Cambridge, UK) were used to visualize the bound antibody. The sections were then lightly counterstained with Harris' haematoxylin.

\section{Quantitative analysis}

The percentage of positively stained lymphocytes on the cytospins was determined by counting 300 cells both before and after stimulation with pokeweed mitogen. Analysis of the endometrial sections for the percentage of cells showing Ki-67 immunoreactivity was performed using a light microscope connected to a video camera and TV monitor to facilitate the counting procedure. For each type of cell (luminal epithelium, gland neck epithelium, superficial stroma, deep gland epithelium and deep stroma), the proportion of positively stained cells was counted in five random areas. The superficial strata (luminal epithelium and stratum compactum) were analysed at $\times 400$ magnification and, in each random field, 30-40 luminal epithelial cells, 20-50 gland neck epithelial cells and 30-50 stromal cell nuclei were counted. In the stratum spongiosum, at $\times 160$ magnification, $80-150$ stromal cells and 130-250 gland epithelial cells were counted in each of the five randomly selected areas. Proliferating cell counts were expressed as a percentage of the total number of cells counted. From the individual percentages in each of the five fields evaluated, the means and SEM were calculated for each type of cell in each sample. The mean percentages of proliferating cells were grouped by cycle phase and analysed using one-way analysis of variance (ANOVA) on logarithmically transformed data. Differences among individual groups were then analysed using Scheffé's test.

\section{Results}

Although only $4 \%$ of the freshly collected peripheral blood lymphocytes reacted with the antibody before culture (Fig. 1a, brown staining of nuclei), $58 \%$ of the cells showed positive staining after stimulation with pokeweed mitogen (Fig. 1b). Predominantly the large lymphocytes that were obviously stimulated could be identified as mitotically active by their immunoreactivity and a number of these also showed mitotic figures. In the endometrial biopsy sections, proliferating cells were clearly identifiable by the strong staining in their nuclei (Fig. 2a); no stained nuclei were detectable in the control sections incubated with $3 \%$ TBS-BSA alone (Fig. 2b). The only visible non-specific staining was that due to endogenous peroxidase activity in
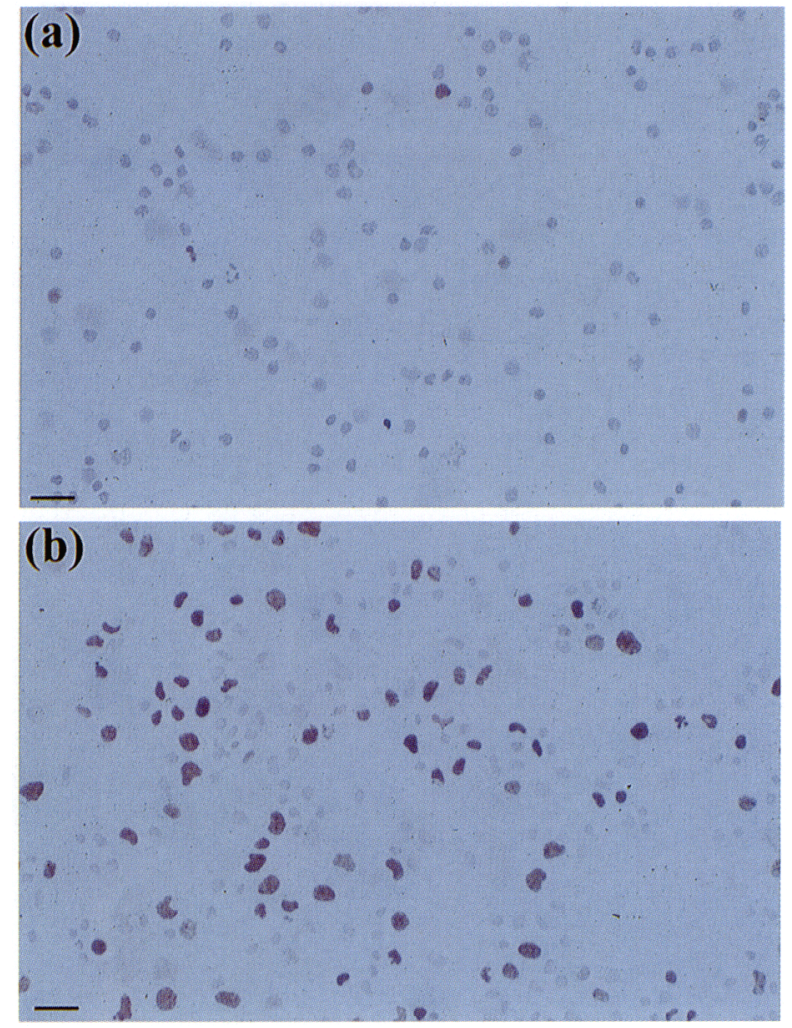

Fig. 1. Immunohistochemical detection of Ki-67 antigen in equine lymphocytes (a) before and (b) after stimulation with pokeweed mitogen. Few cells stain positively immediately after isolation from peripheral blood, but the majority stained strongly after mitogenic stimulation and became much larger. Scale bars represent $20 \mu \mathrm{m}$.

stromal macrophages and siderocytes. However, this presented no problems during analysis because the staining was a much lighter shade of brown and distributed throughout the cytoplasm of the cells rather than being confined to the nucleus (see Fig. 2).

Typical staining patterns observed in the different phases of the reproductive cycle are shown (Fig. 3) and the mean ( \pm SEM) counts for each type of cell are depicted (Fig. 4, each column represents an individual sample). Although there was some variation in the proliferating cell counts in the five fields examined from each biopsy section, this variation was so small it did not detract from the overall pattern observed (Fig. 4). Nonetheless, the variation tended to increase as the means increased, which necessitated logarithmic transformation of the data before statistical tests could be performed (Fowler and Cohen, 1990). This allowed comparison of the mean results for each type of cell to illustrate the highly significant differences among the various stages of the reproductive cycle (Fig. 4). In some animals, leucocytic round cells (lymphocytes and plasma cells) were present, particularly in the superficial stroma of the endometrium, and a surprisingly large number of them stained positively for $\mathrm{Ki}-67$ antigen, irrespective of the stage of the reproductive cycle. Foci of chronic inflammation were easily detectable (Fig. 3a) and such areas could be excluded 

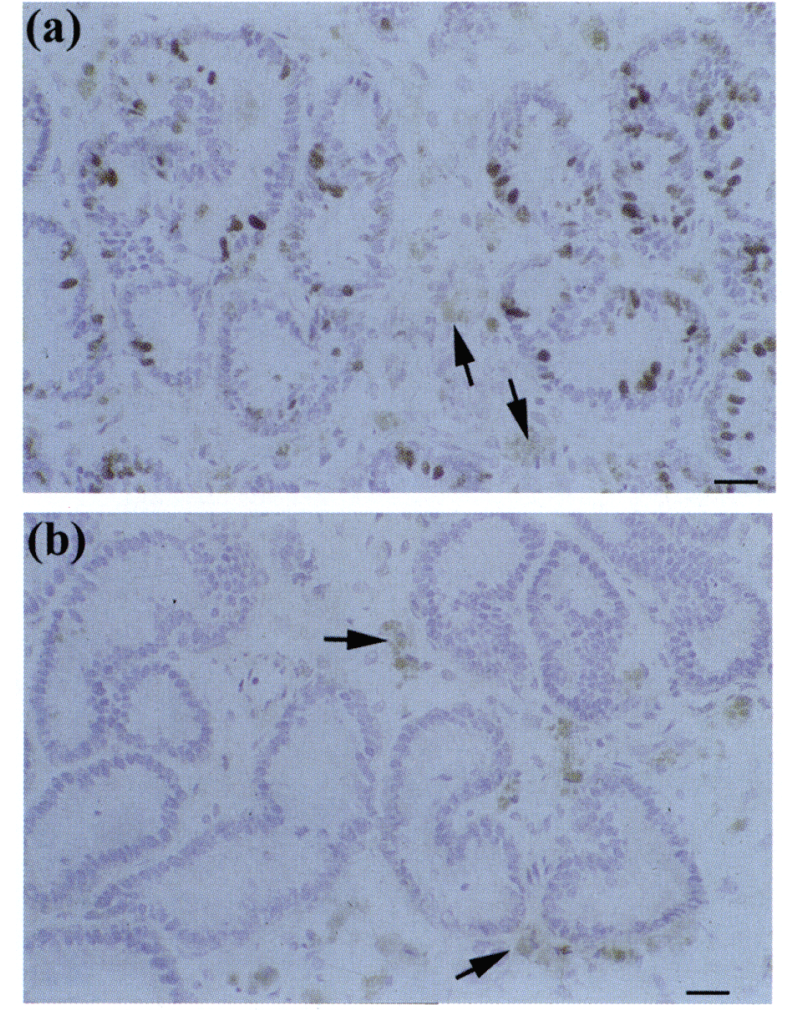

Fig. 2. (a) Equine endometrial biopsy immunostained for the proliferation marker Ki-67 antigen and (b) a negative control section. Proliferating nuclei reacted positively with the MIBI primary antibody (a), whereas this specific staining was absent from the control sections that were incubated with 3\% Tris-buffered saline-BSA alone (b). The non-specific reactions are due to the activity of endogenous peroxidase in stromal macrophages and siderocytes (arrows), but the staining is light, restricted to the cytoplasm of cells and is also present in the control sections. Scale bars represent $20 \mu \mathrm{m}$.

from counting. However, the light microscopic methods did not allow a reliable distinction between positively stained nuclei of fibroblasts, which were occasionally cut transversely, and those of lymphocytes distributed diffusely in the stroma. Two of the samples showed an obvious diffuse infiltration of mononuclear leucocytes into the stratum compactum (Fig. 4, see asterisk). These samples yielded falsely high percentages of proliferating cells for that area and were excluded from further statistical analyses.

During anoestrus, a moderate proliferation rate was observed consistently in the luminal epithelium, and a number of nuclei in the epithelium of the gland necks and the superficial stroma were positively stained (Fig. 3b). Furthermore, the proliferation rate of the luminal epithelial cells was significantly higher $(P<0.01)$ than after day 5 of dioestrus or during prolonged dioestrus (Fig. 4). The proliferation rate of all types of cell in the superficial strata was greatest during oestrus but, similar to the pattern observed in anoestrus, very few cells were mitotically active in the stratum spongiosum (Fig. 3c). The proportion of positively stained nuclei in the luminal epithelium, the gland neck epithelium and the superficial stroma remained very high for 3 days after the end of oestrus, before decreasing to the basal values typical of dioestrus. The proliferation rates of these three types of cell was significantly higher $(P<0.01)$ during oestrus and very early dioestrus (days 1-3), than at any other stage in the nonpregnant reproductive cycle (Fig. 4).

Between day 3 and day 7 after ovulation, a sudden marked and highly significant $(P<0.01)$ increase was observed in the proliferation rate of the epithelial cells of the secretory portions of the endometrial glands (Fig. 4). On day 3 , all the cross-sections in the stratum spongiosum showed increased mitotic activity, whereas the proliferation rate of the cells in the superficial strata remained high (Fig. 3d). However, by day 5 of dioestrus there were almost no positively stained nuclei in the luminal epithelium and stratum compactum, and only the secretory gland epithelium remained mitotically active (Fig. 3e). Samples from two mares from which biopsies were taken on days $3-5$ of dioestrus showed evidence of chronic infiltrative endometritis, stromal fibrosis and degenerative 'gland nest' formation. The gland cross-sections in these areas did not display the usual pattern of increased epithelial cell proliferation observed in the normal surrounding glands (Fig. 3f). After day 7 of dioestrus, the proliferation rate in all types of cell and the strata decreased to basal values (Fig. $3 g$ ) and the number of positively stained nuclei also remained very small throughout prolonged dioestrus of a duration of

Fig. 3. Typical staining patterns observed with immunohistochemical localization of $\mathrm{Ki}-67$ antigen to detect proliferating cells in sections of equine endometrial biopsies obtained at different stages of the non-pregnant reproductive cycle. (a) Foci of chronic inflammation in the stroma (arrows) are characterized by accumulation of positively stained lymphocytes. (b) During anoestrus, a moderate proliferation rate is observed in the luminal epithelium (LE) and a few nuclei are positively stained in the epithelium of the gland necks (GN) and in the superficial stroma of the stratum compactum (bracket). (c) Two examples of biopsies from mares in oestrus. There is a marked increase in the proliferation rates in the luminal epithelium (LE), gland neck epithelium (GN) and the stromal cells of the stratum compactum (bracket), but there is no significant mitotic activity in the deeper strata. (d) On day 3 of dioestrus, there is a marked increase in positively stained nuclei in the deeper secretory portions of the endometrial glands that are observed in the stratum spongiosum (bracket). (e) By day 5 of dioestrus, positively stained nuclei are absent from the superficial strata and only the deep secretory gland epithelium in the stratum spongiosum (bracket) is mitotically active. In this specimen, several siderocytes can be recognized by their false positive cytoplasmic staining (arrows). (f) Biopsy taken from a subfertile mare with endometrosis on day 5 of dioestrus. The dilated gland cross-sections located in the gland nest that is surrounded by layers of fibrosis do not display the normal pattern of increased epithelial cell proliferation seen at the same stage in the adjacent healthy glands. (g) By day 10 of dioestrus, proliferation rates in all types of cell and the strata of the endometrium have decreased to basal values. (h) Biopsy from a non-pregnant mare that had shown prolonged dioestrus (persistently high serum progesterone concentrations) for 35 days. The number of positively stained nuclei has remained at a basal value. A few large macrophages, which are recognized by the false positive cytoplasmic staining (arrows), are present in the deep stroma. Scale bars represent $100 \mu \mathrm{m}$. 

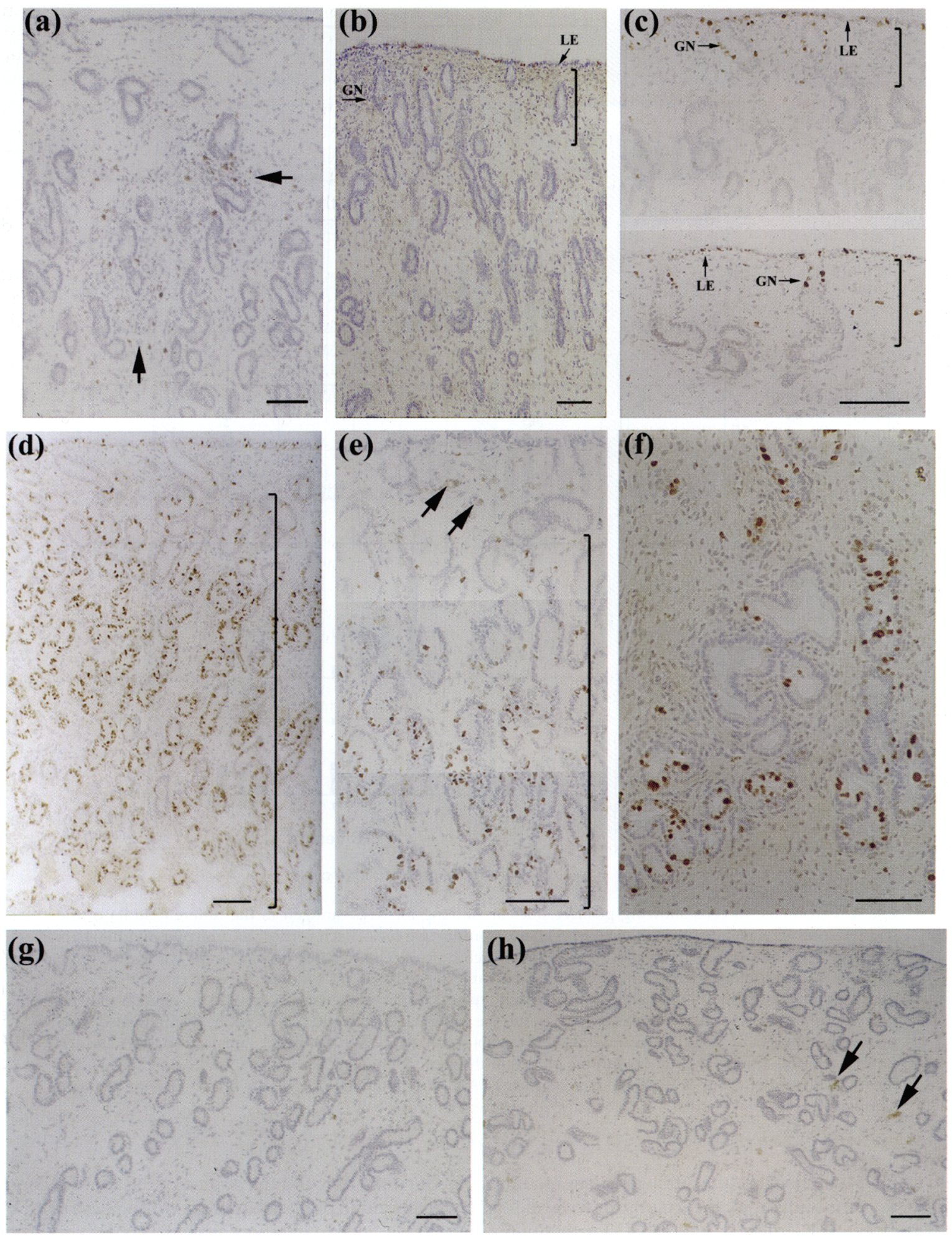

Fig. 3. For legend see facing page.

$31-40$ days (Fig. $3 \mathrm{~h}$ ). No obvious pattern of cell proliferation was detectable in the deep stroma of the stratum spongiosum and the number of positively stained nuclei remained extremely small $(<3 \%)$ in all samples examined (Fig. 4).

\section{Discussion}

The monoclonal antibody MIB1 directed against the human $\mathrm{Ki}-67$ antigen enabled proliferating cells in equine blood and tissue samples to be counted. The marked increase in 


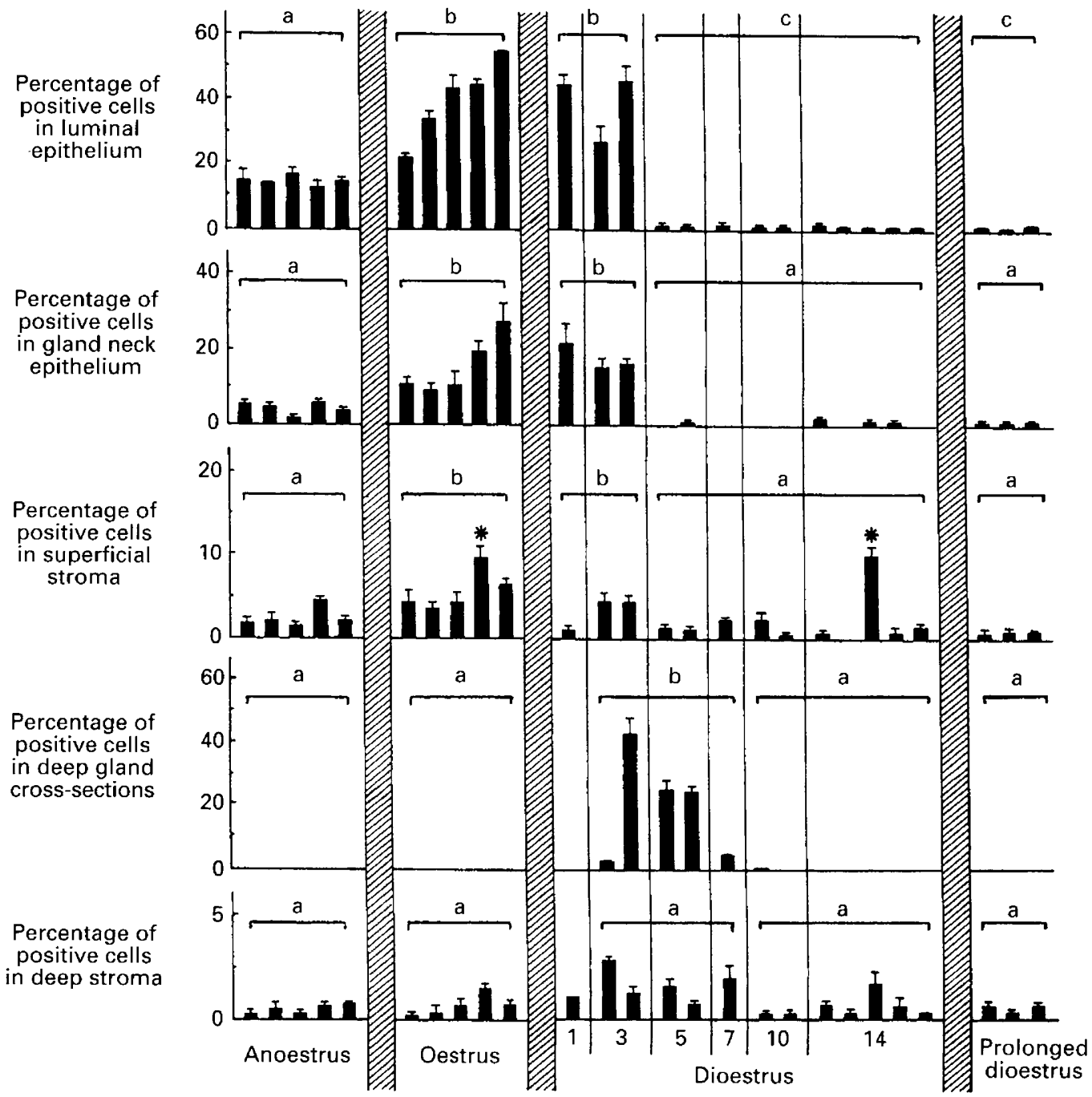

Stage of the reproductive cycle

Fig. 4. Percentage of cells showing positive nuclear staining for Ki-67 antigen in the different strata of the endometrium of the mare during the non-pregnant reproductive cycle. Each vertical column of individual bars represents one biopsy specimen and the results for each type of cell are depicted as a single bar showing the mean (+ SEM) percentage derived from counting the ratio of positively stained nuclei in five random areas on each section. (Note the different scale used for each type of cell.) Specimens marked with an asterisk showed diffuse infiltration of proliferating lymphocytes into the superficial stroma that could not be distinguished from positively stained fibroblast nuclei and, thus, the results were excluded from further statistical analysis. In each type of cell, the differences among various phases of the reproductive cycle were analysed by comparing the mean results with a one-way analysis of variance (ANOVA) followed by Scheffés test. Groups that are significantly different $(P<0.01)$ are labelled with different letters $(a, b$ or $c)$.

positively stained lymphocytes after mitogenic stimulation in culture was very similar to the results described for human lymphocytes (Gerdes et al., 1983). Furthermore, systematic histochemical analysis of endometrial biopsies taken at different stages of the non-pregnant reproductive cycle agree broadly with the observations of Gilbert (1992, abstract) who, by counting mitotic figures, noted that most luminal epithelial cells divide in late oestrus, whereas most glandular epithelial cells divide on day 4 of dioestrus. In the present study, cells of the superficial strata of the endometrium, comprising the luminal epithelium, the gland neck epithelium and the stroma of the stratum compactum, were found to proliferate mainly during oestrus, and a rapid decrease in proliferation was observed very soon after ovulation. Thus, multiplication of these cells appears to be closely associated with the presence of oestrogens during the follicular phase of the cycle (Palmer and Jousset, 1975; Allen WR et al., 1995). In contrast, proliferation of the cells in the deeper secretory portions of the endometrial glands is restricted to a brief phase during early dioestrus, when the serum progesterone concentrations are still increasing (Palmer and Jousset, 1975; Allen and Sanderson, 1987). The 
equine embryo remains in the oviduct for the first 5-6 days after fertilization (Oguri and Tsutsumi, 1972; Skidmore et al., 1989). This slow rate of oviductal transport may be related to a need for the secretory epithelium of the endometrial glands to proliferate before it is able to secrete sufficient histotrophe for the embryo when it enters the uterus on day 6 . This increased proliferation after ovulation would also explain what appears to be a greater number (Hammond and Wodzicki, 1941) and increased tortuosity (Kenney, 1978) of deeper endometrial glands in sections of dioestrous biopsies compared with those obtained from oestrous or anoestrous mares.

The increased number of proliferating luminal epithelial cells during anoestrus was reminiscent of the proliferation pattern seen during oestrus. However, it is unclear whether this represented a true picture for mares that are not under the influence of steroid hormones because the anoestrous mares were not ovariectomized. Although these animals had only very small follicles in their ovaries at the time of sampling, the possibility cannot be excluded that they had low but sufficient concentrations of oestrogens in the peripheral circulation to stimulate some epithelial proliferation.

Gilbert (1992) was the first to suggest that the luminal and glandular epithelia in the equine endometrium should be regarded as functionally distinct cell populations since they show different responses to cyclic hormone changes. Furthermore, several studies have shown marked differences in secretory activity in the deep glandular epithelium compared with the luminal epithelium and gland necks. For example, the luminal epithelium stains positively with periodic acid-Schiff (PAS) throughout the oestrous cycle (Gilbert, 1992) and the surface and gland neck epithelial cells both contain predominantly carboxylated acid mucins (Freeman et al., 1990). On the other hand, PASpositive material is found in the deeper endometrial gland epithelium only during the luteal phase (Gilbert, 1992) and the cytoplasmic content of the glands proper consists mainly of glycogen (Freeman et al., 1990). Likewise, after 40 days of gestation, the production of large amounts of the potent mitogen epidermal growth factor (EGF) is confined strictly to the secretory region of the glands (Stewart et al., 1994). In the present study, proliferative activity in the epithelium of the deep secretory glands peaked at a completely different stage in the cycle from the peak activity in the luminal epithelium and the gland necks. This finding also supports the argument that the epithelial layers in the equine endometrium consist of two distinctly different populations of cells.

Similar to the current observations in the horse, the mitotic activity of oestrogens in the endometrium of rodents is restricted to the luminal and gland neck epithelia. In mice (Finn and Martin, 1967), rats (Chaudhury and Sethi, 1970; Tachi et al., 1972; Marcus 1974a) and guinea-pigs (Marcus, 1974b; Mehrotra and Finn, 1974), the proliferation rate of the luminal epithelium peaks around the time of ovulation, whereas that of the glandular epithelium shows a marked increase a few days later (reviewed in Weitlauf, 1994). When oestrogen injections are given to ovariectomized mice, the response is similar to the pattern observed in the cycle, and the luminal epithelium starts to proliferate within $24 \mathrm{~h}$ of oestrogen administration. However, 3 days after cessation of treatment, when the luminal epithelium has stopped proliferating, a wave of mitosis is seen in the glands which occurs in the absence of progesterone. Concurrent administration of progesterone inhibits the mitotic response in both types of epithelium (Finn and Martin, 1973; Weitlauf, 1994). Therefore, as has been suggested for rodents, the proliferation of the secretory gland epithelium during early dioestrus in horses is likely to be a delayed response to a decrease in peripheral oestrogen concentrations rather than a response that is initiated directly by the increase in progesterone. When the corpus luteum has matured, high progesterone concentrations probably terminate the early dioestrous proliferation of the glandular epithelium and cause a switch to secretory activity. Increased serum progesterone concentrations in the absence of pregnancy can persist for extended periods in a subpopulation of mares in which the corpus luteum fails to lyse at the normal time and which thus do not return to oestrus (Allen et al., 1974; Stabenfeldt et al., 1974). No increase in the mitotic rate of any type of cell was observed in the endometrium of mares that were in this type of prolonged dioestrus.

Age-related degenerative changes that occur in the endometrium of the mare, termed endometrosis (R. M. Kenney, quoted in Allen, 1993), cause deposition of fibrous tissue in the stroma and grouping of endometrial gland cross-sections into the characteristic 'gland nests' described by Kenney (1978). These degenerate glands also show functional abnormalities. For example, the epithelium shows an increased number of ciliated cells and atypical mucus production (Causey et al., 1997), and recent results have demonstrated an abnormal staining pattern for P19, a progesterone-dependent lipocalin (F. Stewart, unpublished). Similarly, the expression of EGF mRNA in the epithelium of the secretory portions of the glands after day 40 of gestation is much reduced in the dilated glands associated with gland nests (Gerstenberg et al., 1997) and endometrial cups (Lennard et al., 1995). Therefore, it is not surprising that the normal early dioestrous proliferation was not observed in some gland nests and in glands surrounded by chronic infiltration of leucocytes. These damaged epithelial cells in the dilated glands are obviously not able to respond adequately to normal endocrine stimuli, a phenomenon that may be related to abnormal expression of hormone receptors (Aupperle et al., 1997). This asynchrony has been proposed as a cause of the decreased fertility in mares with endometriosis (Schoon et al., 1997).

Proliferating lymphocytes were observed in the endometrium of several animals. In contrast to the human or rodent endometrium, in which the predominant types of leucocyte are large granular lymphocytes (Hunt, 1994), T cells are the dominant leucocytes present in the healthy endometrium of horses. The $\mathrm{T}$ cells are distributed diffusely in the stroma or accumulate as small lymphocyte aggregates and are part of the uterine defence mechanisms of normal cyclic mares (Watson and Dixon, 1993; Grünig et al., 1995). The number of $\mathrm{T}$ cells increases markedly in mares with chronic persistent endometritis (Ricketts, 1975; Kenney, 1978; Watson and Dixon, 1993). T cells are also found in lymphatic vessels or in veins located in the endometrial stroma, for example beneath the endometrial cups during pregnancy, 
and cell trafficking is clearly one way in which these cells appear in the endometrial stroma (Grünig et al., 1995). In addition, the present study demonstrates that local proliferation can contribute to an increase in the number of lymphocytes.

In summary, immunohistochemical detection of the proliferation marker Ki-67 antigen enabled determination of mitotic activity during the different phases of the reproductive cycle in the various types of cell that constitute the equine endometrium. The technique will be a valuable adjunct in future studies that aim to characterize the endometrial responses in fertile and subfertile mares, for example during pregnancy, or to determine the influences of exogenous steroid hormones and other therapeutic measures.

This work was kindly supported by the Thoroughbred Breeders' Association of Great Britain and the Horserace Betting Levy Board.

\section{References}

Allen GP, Yeargan M, Costa LRR and Cross R (1995) Major histocompatibility complex class 1-restricted cytotoxic T-lymphocyte responses in horses infected with equine herpes virus 1 Journal of Virology $69606-612$

Allen WR (1993) Equine endometritis. Proceedings of the John P. Hughes International Workshop Equine Veterinary Journal 25 184-193

Allen WR and Sanderson M (1987) The value of a rapid progesterone assay (AELIA) in equine stud veterinary medicine and management Proceedings of the 9th Bain-Fallon Memorial Lectures, AEVA Sydney pp 75-82

Allen WR, Stewart F, Cooper MJ, Crowhurst RC, Simpson DJ, McEnery RJ, Greenwood RES, Rossdale PD and Ricketts SW (1974) Further studies on the use of synthetic prostaglandin analogues for inducing luteolysis in mares Equine Veterinary Journal $631-36$

Allen WR, Mathias S, Lennard SN and Greenwood RES (1995) Serial measurement of peripheral oestrogen and progesterone concentrations in oestrous mares to determine optimum mating time and diagnose ovulation Equine Veterinary Journal 27 460-464

Aupperle H, Schoon H-A, Özgen S, Klug E and Bartmann CP (1997) Immunohistochemical methods for the characterization of physiological and pathological endometrial functions Pferdeheilkunde 13551 (Abstract)

Ball BA, Little TV, Hillman RB and Woods GL (1986) Pregnancy rates at days 2 and 14 and estimated embryonic loss rates prior to day 14 in normal and subfertile mares Theriogenology 26 611-619

Bartelmez GW (1957) The phases of the menstrual cycle and their interpretation in terms of the pregnancy cycle American journal of Obstetrics and Cynecology $74931-955$

Bracher V and Allen WR (1992) Videoendoscopic evaluation of the mare's uterus: I. Findings in normal fertile mares Equine Veterinary fournal 24 274-278

Causey RC, Ginn PS and LeBlanc MM (1997) Mucus production of the equine endometrium: effect of cycle stage and susceptibility to equine endometritis Pferdeheilkunde 13543 (Abstract)

Chaudhury RR and Sethi A (1970) Effects of an intra-uterine contraceptive device on mitosis in the rat uterus on different days of pregnancy lournal of Reproduction and Fertility 22 33-40

Dowsett M, Howell R, Salter J, Thomas NM and Thomas EJ (1995) Effects of the pure anti-oestrogen ICI 182780 on oestrogen receptors, progesterone receptors and Ki67 antigen in human endometrium in vivo. Hunan Reproduction 10 262-267

Falini B, Flenghi L and Fagioli M (1989) Evolutionary conservation in various mammalian species of the human proliferation-associated epitope recognised by the Ki67 monoclonal antibody journal of Histochemistry and Cytochemistry 37 1471-1479

Ferenczy A, Bertrand G and Gelfand M (1979) Proliferation kinetics of human endometrium during the normal menstrual cycle American journal of Obstetrics and Gynecology $133859-867$

Finn CA and Martin L (1967) Patterns of cell division in the mouse uterus during early pregnancy Journal of Endocrinology 39 593-597

Finn CA and Martin L (1973) Endocrine control of gland proliferation in the mouse uterus Biology of Reproduction 8 585-588
Fowler J and Cohen L (1990) Chapter 10: Data transformation. In Practical Statistics for Field Biology pp 83-89. John Wiley \& Sons, Chichester

Freeman KP, Roszel JF, Slusher SH and Castro M (1990) Variation in glycogen and mucins in the equine uterus related to physiologic and pathologic conditions Theriogenology 33 799-808

Gerdes J, Schwab U, Lemke H and Stein H (1983) Production of a mouse monoclonal antibody reactive with a human nuclear antigen associated with cell proliferation International Journal of Cancer 31 13-20

Gerdes J, Lemke H, Baisch H, Wacker H-H, Schwab U and Stein H (1984) Cell cycle analysis of a cell proliferation-associated human nuclear antigen defined by the monoclonal antibody Ki-67 Journal of Immunology 133 1710-1715

Gerstenberg C, Stewart F and Allen WR (1997) The influence of endometrosis on epidermal growth factor (EGF) gene expression in the endometrial glands of the mare Pferdeheilkunde 13531 (Abstract)

Gilbert RO (1992) Cyclical changes in equine endometrial histology Proceedings of the 12th International Conference on Animal Reproduction The Hague pp 1867-1869 (Abstract)

Grünig G, Triplett L, Canady LK, Allen WR and Antczak DF (1995) The maternal leucocyte response to the endometrial cups in horses is correlated with the developmental stages of the invasive trophoblast cells Placenta 16 539-559

Hall PA and Levison DA (1990) Assessment of cell proliferation in histological material Journal of Clinical Pathology 43 184-193

Hammond J and Wodzicki K (1941) Anatomical and histological changes during the oestrous cycle in the mare Proceedings Royal Society London, Series B 130 1-23

Hunt JS (1994) Immunologically relevant cells in the uterus Biology of Reproduction 50 461-466

Johannisson E, Parker RA, Landgren B-M and Dicfalusy E (1982) Morphometric analysis of the human endometrium in relation to peripheral hormone levels Fertility and Sterility 38 564-571

Kenney RM (1978) Cyclic and pathological changes of the mare endometrium as detected by biopsy, with a note on early embryonic death Journal of the American Veterinary Medical Association 172 241-262

Kenney RM and Doig PA (1986) Equine endometrial biopsy. In Current Therapy in Theriogenology 2nd Edn pp 723-729 Ed. DA Morrow. WB Saunders Co., Philadelphia

Key G, Becker MHG, Baron B, Duchrow M, Schlüter C, Flad H-D and Gerdes J (1993) New Ki-67-equivalent murine monoclonal antibodies (MIB 1-3) generated against bacterially expressed parts of the Ki-67 cDNA containing three 62 base pair repetitive elements encoding for the Ki- 67 epitope Laboratory Investigation 68 629-636

Leblond CP (1981) The life history of cells in renewing systems American Journal of Anatomi 160 114-158

Lennard SN, Stewart F, Allen WR and Heap R (1995) Growth factor production in the pregnant equine uterus Biology of Reproduction Monograph 1 161-170

Marcus GJ (1974a) Mitosis in the rat uterus during the estrous cycle, early pregnancy and early pseudopregnancy Biology of Reproduction 10 447-452

Marcus GJ (1974b) Hormonal control of proliferation in the guinea-pig uterus Journal of Endocrinology 63 89-97

Mehrotra SN and Finn CA (1974) Cell proliferation in the uterus of the guinea pig Journal of Reproduction and Fertility 37 405-409

Oguri N and Tsutsumi Y (1972) Non-surgical recovery of equine eggs, and an attempt at non-surgical egg transfer in horses Journal of Reproduction and Fertility 31 187-195

Padykula HA (1989) Regeneration in the primate uterus. The role of stem cells. In Biology of the Uterus 2nd Edn pp 279-288 Eds RM Wynn and WP Jollie. Plenum Medical Book Company, New York

Palmer E and Jousset B (1975) Urinary oestrogen and plasma progesterone levels in non-pregnant mares Journal of Reproduction and Fertility Supplement 23 213-221

Pollard JW (1990) Regulation of polypeptide growth factor synthesis and growth factor-related gene expression in the rat and mouse uterus before and after implantation Journal of Reproduction and Fertility 88 721-731

Ricketts SW (1975) The technique and clinical application of endometrial biopsy in the mare Equine veterinary Journal 7 102-108

Schoon H-A, Schoon D and Klug E (1997) Die Endometriumsbiopsie bei der Stute im klinisch-gynäkologischen Kontext Pferdeheilkunde 13 453-464

Skidmore J, Boyle MS, Cran D and Allen WR (1989) Micromanipulation of equine embryos to produce monozygotic twins Equine Veterinary Journal Supplement 8 126-128

Slayden WD, Hirst JJ and Brenner RM (1993) Estrogen action in the 
reproductive tract of rhesus monkeys during antiprogestin treatment Endocrinology 132 1845-1856

Stabenfeldt GH, Hughes JP, Evans JW and Neely DP (1974) Spontaneous prolongation of luteal activity in the mare Equine Veterinary Journal 6 158-162

Stewart F, Power CA, Lennard SN, Allen WR, Amet L and Edwards RM (1994) Identification of the horse epidermal growth factor (EGF) coding sequence and its use in monitoring EGF gene expression in the endometrium of the pregnant mare Journal of Molecular Endocrinology 12 341-350
Tachi C, Tachi S and Lindner HR (1972) Modification by progesterone of oestradiol-induced cell proliferation, RNA synthesis and oestradiol distribution in the rat uterus Journal of Reproduction and Fertility 31 59-76

Watson ED and Dixon CE (1993) An immunohistological study of MHC class II expression and T lymphocytes in the endometrium of the mare Equine Veterinary Journal 25 120-124

Weitlauf HM (1994) Biology of implantation. In The Physiology of Reproduction 2nd Edn pp 391-429 Eds E Knobil and JD Neill. Raven Press Ltd, New York 